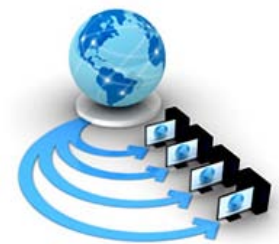

Volume 8, No. 9,November-December 2017

International Journal of Advanced Research in Computer Science

REVIEW ARTICLE

\author{
Available Online at www.ijarcs.info
}

\title{
ANALYSIS OF SMART STORE SOLUTIONS USING PROXIMITY TECHNOLOGIES
}

\author{
Shreyas Dighe, Mokshit Jain \\ Department of Computer Engineering, \\ SVKM'S NMIMS's Mukesh Patel School of Technology \\ Management and Engineering \\ Mumbai, India \\ Prof.Mohini Reddy \\ Assistant Professor, \\ Department of Computer Engineering, \\ SVKM'S NMIMS's Mukesh Patel School of Technology \\ Management and Engineering \\ Mumbai, India
}

\author{
Abhinandan Desai, Yug Desai, \\ Department of Computer Engineering, \\ SVKM'S NMIMS's Mukesh Patel School of Technology \\ Management and Engineering \\ Mumbai, India \\ Prof. Prathamesh Churi \\ Assistant Professor, \\ Department of Computer Engineering, \\ SVKM'S NMIMS's Mukesh Patel School of Technology \\ Management and Engineering \\ Mumbai, India
}

\begin{abstract}
The retail industry is on a decline due to the redirection of the consumers towards the e-commerce business. In order to prevent this trend from severely damaging the business of offline stores, it is necessary to understand the drawbacks of the current offline retail sector. The timeintensive exercise and the lack of convenience are the major reasons why people evade the offline shopping. This paper proposes a smart store solution, based on Proximity technologies, not only as an alternative to conventional methods but also as an advancement to the existing systems in place. It also consists of an informative mobile application that assists the customer activities in the scope of the store, beginning from his entry in the smart parking area to his exit after a successful checkout via digital payments. This innovation will help revive the stagnating offline retail industry by adding unique and attractive features that make offline shopping more intuitive, engaging, efficient and convenient.
\end{abstract}

Keywords: RFID, Smart store, Predictive Analytics, Indoor Navigation, NFC.

\section{INTRODUCTION}

The retail industry is on a decline due to the sudden advent and an attempted market capture by the e-commerce websites. The proposed project smart.store blends the domains, Embedded Systems and Big Data Analytics with an aim to reduce the strain on the retail industry by eliminating the drawbacks of the current scenario with the use of proximity technologies, interfaced over the embedded systems / SOCs and further augmenting this through data collection and predictive analytics.

A smart store promises an effortless experience for the customer. In the smart.store the primitive goal is to implement smart shelves and smart carts using the RFID technology and enable a self-checkout in-app feature for digital payments. It dwells on the concept of going cashless and maximizes automation in the process of shopping. The project relies on a document-oriented database, and captures and archives the user behaviour and purchases for predictive modelling. Through the proposed application, the Customers can easily locate the products via the in-app indoor navigation system, avoid theinconvenience caused in queues, and make

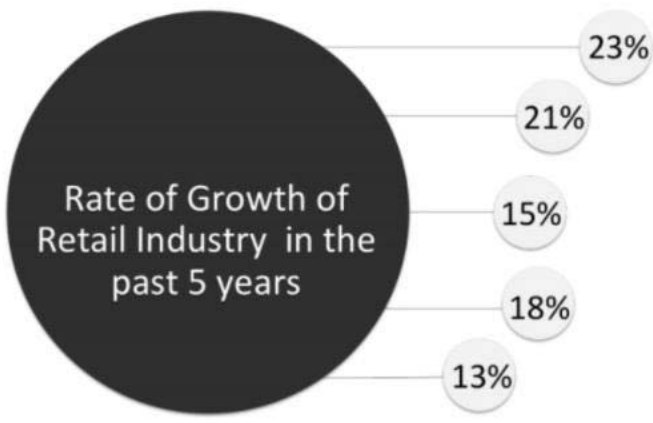

Figure 1. Rate of growth of Retail Industries

buying decisions based on the context-relevant personalized promotions.

The Figure 1 shows the rate of growth of the retail industry has fluctuated significantly. The primary cause of this fluctuation is the progressively growing e-commerce market. So, even though the market share of the Off-line market is dominant, the decline in the growth of the Retail industry has landed the Brick and Mortar Stores in a difficult situation. The dying retail industry demands a change in the conventional system in order to recapture and re-engage the lost customer 
base. It is a well known fact today that the retail stores can never match the price or the customer expectation as compared to the e-commerce stores, primarily because of the difference in the Business ideologies. An off-line store focuses more over the sales and revenue while the on-line platforms are targeting the MAU as the primary source of business revenue. Monetary profit is a secondary factor in their case. Because of this, they even sell their products at loss, because that is how they can engage the user onto their platform to earn profits over the long run from this user.

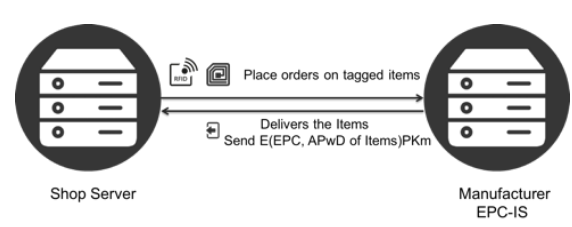

Figure 2. A typical retailer-manufacturer authentication

This paper focuses on developing a Smart store solution using various proximity technologies. The following section contains an extensive review of various modules necessary to build this store. In Section III of this paper we propose our architecture and finally we conclude our paper in Section IV.

\section{LITERATURE REVIEW}

We have studied various Research Papers in our Domainto better understand the need of these latest proximity technologies in the Retail Market. The current scenario is ofusing conventional barcodes. It is an an optical, machinereadable representation of the data, which represents a certain identifiable data about the object carrying the barcode. But,the major disadvantage of the current barcode system is thatthe products are scanned one at a time. So, if the number ofproducts increases, the scanning time also increases.A simplelow-cost, efficient solution to this problem is to utilise theRFID technology to integrate the Smart shopping Carts(SSC)[1] [7]. Table I shows an overview of a smart store system [1]

[2] [3] [4] [5]

Also, Table II analyses the previously proposed smart store systems [6] [7] [8] [9] [10].

Since the solution aims to reduce human interaction in the whole purchasing process and also, in a way, provide the customer with a private experience, it is also essential for the customer to have confidence in the data collection and payment systems of the solution.Figure 2 shows a typical retailer-manufacturer authentication [11].This brings us to the very important question of securing the payment method and customer data while the information is being exchanges between the myriad components of the system between the cart, applications and cloud. At the same time there are design issues which could lead to complications and inconsistencies which need to be dealt with. The papers in Table III presented some of the solutions [11] [12] [13] [14].

While providing the customer a great deal of convenience, we must also find a way to channel the large chunk of data to the benefit of the business as well as the consumers. This is where predictive analysis comes into the picture. By analysing the customer behaviour and purchase patterns, the business can plan in advance the customer requirements, and also alert the customers in case of relevant offers. The papers analyzed in Table IV deal with this issue and also deals with the smart billing systems that are secure and require minimum human interventions [15] [16] [17].

In order to make the smart shopping solution truly smart, certain additional features apart from smart cart are required. Two of the most important among these are smart shelvesand indoor navigation. These features can be of great use in automated inventory management, database updating, tracking of customer behaviour, providing great convenience to the customers in maze-like super stores and providing additional failsafe in the overall system. Such systems will require an efficient network to collect, monitor and push real-time data. Table $\mathrm{V}$ provides the research done under this domain [18] [19] [20] [21] [22].

A smart Shelf is a technique used for smart inventory control over the shelves in the stores. For example, in a librarymanagement system, smart shelves are capable of keeping the count of the books on shelf and detect misplaced books [18]. The system is expensive though, since it involves tagging each book individually for the smart shelves. But, when used in scenarios like merchant stores and warehouses with high-value items, the smart shelves play a vital role in the automated inventory control.

Rebecca Minkoff inaugurated its first store using smart technology in New York in 2014. The luxury brand is a retailer of clothing, bags and accessories. The store features RFID based self-checkout stations and magic mirrors in the changing rooms. The store has been dubbed as the Store of the future [23].

All the products have a unique RFID tag attached to it. Through the integrated RFID system, the store can recognize which product the shopper has carried to the changing room. Inside the changing room, magic mirrors have been installed which also acts as touch screen. Figure 4 . shows the magic mirror as installed inside the store [23].On this screen the customer can find the variants of the products such as different colors and sizes or other such related products. As soon as the shopper enters the changing room, RFID tag of the product isself-checkout system based on RFID technology. Customers can make payments via Apple iPad/card readers at the pointof-sale. There are RFID readers that detect the hard RFID tags and generate the product list. Once the payment is done, security tags are unlocked and can be removed. It also provides and angle of privacy to the customers. They do not have to wait in queues or even interact with anyone during the entire process. 
Table I:NEED OF RFID, AND SYSTEM OVERVIEW

\begin{tabular}{|c|c|}
\hline Paper Title & Analysis \\
\hline $\begin{array}{l}\text { RFID Cloud Smart Cart } \\
\text { System,YerlanBerdaliyev, } \\
\text { Alex } \\
\text { Pappachen James, } 2016 \\
\text { [1] }\end{array}$ & $\begin{array}{l}\text { Using RFID tags instead of } \\
\text { traditional barcodes, one can } \\
\text { significantly reduce the } \\
\text { waiting time in queues in } \\
\text { stores. Also, having a RFID } \\
\text { reader installed on the cart, an } \\
\text { automatic live bill can be } \\
\text { generated }\end{array}$ \\
\hline $\begin{array}{l}\text { Arduino based Smart } \\
\text { Cart, Dr.Shefali Gupta, } \\
\text { Ashmeet Kaur, AvniGarg, } \\
\text { Abhishek Verma, Akshay } \\
\text { Bansal, Arvinder Singh, } \\
2013 \text { [2] }\end{array}$ & $\begin{array}{l}\text { The paper proposes an } \\
\text { architecture based on } \\
\text { ATMEGA and AVR } \\
\text { microcontrollers (Arduino) } \\
\text { RFID Readers (EM-18), } \\
\text { Passive RFID tags, RS232 } \\
\text { (MAX232) for seria } \\
\text { communication at POS, and a } \\
\text { Locking Mechanism using } \\
\text { L293D Motor Drivers to } \\
\text { implement a smart shopping } \\
\text { cart whose prototype has been } \\
\text { tested and verified. }\end{array}$ \\
\hline $\begin{array}{l}\text { The Introduction and } \\
\text { Design of a New Form of } \\
\text { Supermarket: Smart } \\
\text { Market, Fangwei Zheng, } \\
\text { Jeffrey Huang, Mark } \\
\text { Meagher, 2009 [3]. }\end{array}$ & $\begin{array}{l}\text { An information acquisition } \\
\text { model is developed along } \\
\text { with a secure checkout aisle, } \\
\text { shielded at the POS to avoid } \\
\text { collisions. The limiting switch } \\
\text { controlling the shield ensures } \\
\text { swift mechanism and prevents } \\
\text { shoplifting. High-value goods } \\
\text { may demand preserving RFID } \\
\text { tags for warranty purposes } \\
\text { while the FMCG goods may } \\
\text { not do so. The process is still } \\
\text { time consuming and the cos } \\
\text { to create the discussed POS } \\
\text { zone will be high. }\end{array}$ \\
\hline $\begin{array}{l}\text { RFID based Smart } \\
\text { Shopping: An Overview, } \\
\text { Zeeshan Ali and } \\
\text { ReenaSonkusare, } 2014 \\
\text { [4]. }\end{array}$ & $\begin{array}{l}\text { It proposes a RFID based } \\
\text { system to assist the buyers to } \\
\text { make informed purchases } \\
\text { while still having a hands-on } \\
\text { experience of the product } \\
\text { RFID technology is used in } \\
\text { the model and live bill is also } \\
\text { generated so shoppers can } \\
\text { stay within budget. The mode } \\
\text { also studies the cart location } \\
\text { and analyses consume } \\
\text { behaviour and patterns. A } \\
\text { secure communication } \\
\text { channel is needed. }\end{array}$ \\
\hline
\end{tabular}

\begin{tabular}{|l|l|}
\hline $\begin{array}{l}\text { A Low Cost Smart } \\
\text { Shopping Facilitator }\end{array}$ & $\begin{array}{l}\text { The passive RFID tags } \\
\text { mounted on shelves are } \\
\text { For Visually Impaired, } \\
\text { identifiers to each product and } \\
\text { M. MathanKumar, N. } \\
\text { Sugandhi. , 2013 [5]. }\end{array}$ \\
& $\begin{array}{l}\text { a unique audio file, recorded } \\
\text { by the APR9600 IC, is played } \\
\text { through the speaker. On } \\
\text { product choice completion, a } \\
\text { mechanical switch triggers the } \\
\text { automated billing via Zigbee. } \\
\text { It has a high societal impact } \\
\text { and effectively enables the } \\
\text { self-independency in the } \\
\text { blinds. The use of Ultrasonic } \\
\text { sensors and FM transmitters } \\
\text { and receivers is impractical } \\
\text { and has certain design issues. }\end{array}$ \\
\hline
\end{tabular}

Table II:PREVIOUSLY PROPOSED SYSTEMS

\begin{tabular}{|c|c|}
\hline Paper Title & Analysis \\
\hline $\begin{array}{l}\text { Supermarket Shopping } \\
\text { Guide System based on } \\
\text { Internet } \\
\text { Things,ByRong Chen, Li } \\
\text { Peng, Yi } \\
\text { Qin, } 2010 \text { [6] }\end{array}$ & $\begin{array}{l}\text { The proposed System SSSGS, } \\
\text { based on Internet of Things, } \\
\text { consists of active RFID Tags } \\
\text { on the shelves, several readers } \\
\text { within the range, and } \\
\text { handheld devices in every } \\
\text { customer's hand. The whole } \\
\text { system, built on a modular } \\
\text { approach, comprises } \\
\text { Identification, searching and } \\
\text { navigation, information } \\
\text { reception, Advertising, and } \\
\text { Smart Checkout modules. } \\
\text { The implementation makes } \\
\text { use of active tags, expensive } \\
\text { over the passive ones. }\end{array}$ \\
\hline $\begin{array}{l}\text { Development of Smart } \\
\text { Shopping Carts with } \\
\text { Customer-Oriented } \\
\text { Service, Hsin-Han } \\
\text { Chiang, Wan-Ting You, } \\
\text { Shu-Hsuan Lin, Wei-Chih } \\
\text { Shih, Yu-Te Liao, Jin- } \\
\text { Shyan Lee, and Yen-Lin } \\
\text { Chen, 2016 [7] }\end{array}$ & $\begin{array}{l}\text { The smart cart contains an } \\
\text { Arduino micro controller that } \\
\text { contains an RFID reader. } 2 \\
\text { readers are used, one for } \\
\text { reading tags of products and } \\
\text { the other for indoor } \\
\text { navigation. }\end{array}$ \\
\hline $\begin{array}{l}\text { IOT based Interactive } \\
\text { Shopping } \\
\text { Eccosystem, } \\
\text { Abhirup Khanna and Ravi } \\
\text { Tomar, 2016 [8] }\end{array}$ & 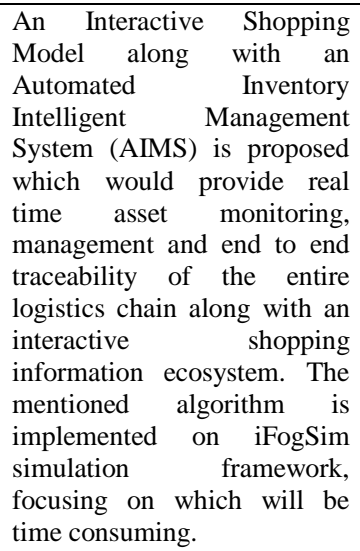 \\
\hline
\end{tabular}




\begin{tabular}{|c|c|}
\hline $\begin{array}{l}\text { A Novel Video } \\
\text { Processing based Cost } \\
\text { Effective Smart Trolley } \\
\text { System for } \\
\text { Supermarkets using } \\
\text { FPGA, Sudhir Rao } \\
\text { Rupanagudi, } \\
\text { FathimaJabeen, Vaishnav } \\
\text { Ram Savarni K } \\
\text { R, SindhuAdinarayana, } \\
\text { Vinay K Bharadwaj, } \\
\text { Karishma R, } \\
\text { VarshaG.Bhat, } 2015 \text { [9]. }\end{array}$ & $\begin{array}{l}\text { A smart trolley system is } \\
\text { proposed which can } \\
\text { maneuver in the store } \\
\text { automatically based on the } \\
\text { Shopping list using certain } \\
\text { Video Processing Techniques. } \\
\text { This is beneficial for elderly } \\
\text { or disabled people. It is not } \\
\text { flexible and shopping list } \\
\text { must be provided prior to } \\
\text { shopping. Secondly, there is } \\
\text { no provision for self-checkout } \\
\text { / digital payments. FPGA Kits } \\
\text { exceed the budget } \\
\text { exponentially and aren't } \\
\text { financially feasible. }\end{array}$ \\
\hline $\begin{array}{l}\text { 3S-cart: A Lightweight, } \\
\text { Interactive Sensor-Based } \\
\text { Cart for Smart } \\
\text { Shopping in } \\
\text { Supermarkets., YouChiun } \\
\text { Wang, Chang-Chen Yang, } \\
2016[10] \text {. }\end{array}$ & $\begin{array}{l}\text { This paper proposes a Sensor } \\
\text { based Smart Shopping cart } \\
\text { (3S-cart system) with sales } \\
\text { promotion and navigation } \\
\text { application. The algorithm for } \\
\text { product navigation } \\
\text { application utilises the A* } \\
\text { method and finds the shortest } \\
\text { path avoiding the crowded } \\
\text { spots in the store. The } \\
\text { proposed sales-promotion } \\
\text { system analyses customer } \\
\text { behaviour on the cases where } \\
\text { either the customer is holding } \\
\text { the trolley, moving it or not. } \\
\text { Thus other methods such as } \\
\text { surveillance systems must be } \\
\text { used for better behaviour } \\
\text { analysis }\end{array}$ \\
\hline
\end{tabular}

Table III:DEALING WITH SECURITY \& DESIGN ISSUES

\begin{tabular}{|c|c|}
\hline Paper Title & Analysis \\
\hline $\begin{array}{l}\text { Security in RFID based } \\
\text { Smart Retail System, } \\
\text { Ravi. V, Aperna. R, } 2016 \\
\text { [11] }\end{array}$ & $\begin{array}{l}\text { Paper presents a simplified } \\
\text { model for realizing RFID } \\
\text { based smart environment for } \\
\text { retail system. It includes Tag- } \\
\text { reader authentication, } \\
\text { encryption of tag information } \\
\text { between tag- reader, shop and } \\
\text { manufacturer server. } \\
\text { By replacing RFID tags on } \\
\text { items, it is possible to reduce } \\
\text { computational and } \\
\text { communication burden on the } \\
\text { item level authenticity to } \\
\text { protect against counterfeit item } \\
\text { sale in gray market. }\end{array}$ \\
\hline $\begin{array}{l}\text { A distributed RFID } \\
\text { Reader Activation } \\
\text { Approach, Weiping } \\
\text { Zhu, Yi Hong, } \\
\text { VaskarRaychoudhury, } \\
\text { Run Zhao and Dong } \\
\text { Wang, 2015 } \\
{[12]}\end{array}$ & $\begin{array}{l}\text { The proposed } 3 \text { layer system } \\
\text { tries to eliminate the three } \\
\text { infrastructural level collisions : } \\
\text { Tag-tag Collisions, Reader- } \\
\text { Tag Collisions, and Reader- } \\
\text { Reader Collisions. It gives an } \\
\text { insight about the practical } \\
\text { design concerns observed in } \\
\text { the environment. It fails to deal } \\
\text { with the tag-tag collision, } \\
\text { which is a practical concern in } \\
\text { cases of inventories like } \\
\text { clothes or any closely-stacked } \\
\text { stock. }\end{array}$ \\
\hline
\end{tabular}

\begin{tabular}{|c|c|}
\hline $\begin{array}{l}\text { Aware and Smart } \\
\text { Member Card: RFID } \\
\text { and } \\
\text { License Plate } \\
\text { Recognition Systems } \\
\text { Integrated Applications } \\
\text { at Parking } \\
\text { Guidance in Shopping } \\
\text { Mall, Cheng-kung, } \\
\text { Yukuang Hsieh, Yung- } \\
\text { hau Wang, Ching-ter } \\
\text { Chang, } \\
2016 \text { [13] }\end{array}$ & $\begin{array}{l}\text { The proposed system applies } \\
\text { certain RFID and LPR } \\
\text { techniques for identification. } \\
\text { Primarily, the SMC identifies a } \\
\text { specific sector and block for } \\
\text { parking regulations. Then, } \\
\text { Digital image processing is } \\
\text { applied using a Custom Haar } \\
\text { Cascade Classifier for License } \\
\text { Plate Recognition. The initial } \\
\text { capital required for this } \\
\text { infrastructure is huge, and } \\
\text { Initial Brand Establishment is } \\
\text { required, along with QA. }\end{array}$ \\
\hline $\begin{array}{l}\text { Cognitive Computing } \\
\text { based Manufacturing } \\
\text { Data Processing for } \\
\text { Internet of Things in } \\
\text { Job-Shop Floor, Chuang } \\
\text { Wang, Pingyu Jiang, } \\
2015 \\
{[14]}\end{array}$ & $\begin{array}{l}\text { A cognitive computing based } \\
\text { manufacturing data processing } \\
\text { is proposed for the huge } \\
\text { erroneous and redundant Data } \\
\text { captured by JFIOT. A layered } \\
\text { reference model of database } \\
\text { saves the different stages and } \\
\text { type's data. Has not been } \\
\text { implemented as of yet. No } \\
\text { specific algorithm has been } \\
\text { established. }\end{array}$ \\
\hline
\end{tabular}

Table IV:AUTOMATED BILLING SYSTEM AND PREDICTIVE ANALYTICS

\begin{tabular}{|c|c|}
\hline Paper Title & Analysis \\
\hline 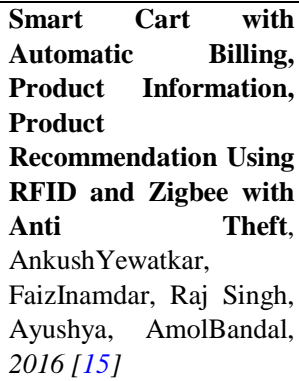 & $\begin{array}{l}\text { A proposed smart shopping } \\
\text { cart system that will profile } \\
\text { purchase patterns and } \\
\text { behaviour. Bayesian network } \\
\text { and ID3 algorithms are used to } \\
\text { track the items added/removed } \\
\text { from the cart and generate a } \\
\text { live bill. }\end{array}$ \\
\hline $\begin{array}{l}\text { Automatic } r \text { product } \\
\text { detection and smart } \\
\text { billing for shopping } \\
\text { using } \\
\text { fi,Ezhilazhagan.C, } \\
\text { Adithya.R, } \\
\text { Burhanuddin.Y. } \\
\text { Charles.F., } \\
\text { 2016 [16] }\end{array}$ & $\begin{array}{l}\text { The paper proposes working } \\
\text { model for shopping with } \\
\text { automatic product detection } \\
\text { and smart billing with the help } \\
\text { of Li-Fi technology. Li-Fi data } \\
\text { transmission takes place in a } \\
\text { region of free band which does } \\
\text { not need license for operation } \\
\text { and it is free of cost. Light } \\
\text { cannot penetrate through walls } \\
\text { and it offers better security. }\end{array}$ \\
\hline
\end{tabular}




\begin{tabular}{|c|c|}
\hline $\begin{array}{l}\begin{array}{l}\text { Design of } \\
\text { Shopping }\end{array} \text { Application } \\
\text { Using } \\
\text { Scanning and Location } \\
\text { Based } \\
\text { Service,Sanga Son and } \\
\text { Yongtae Shin, } \\
\text { Coupon } \\
\text { [17] }\end{array}$ & $\begin{array}{l}\text { A smartphone shopping } \\
\text { application is designed that } \\
\text { scans products' barcode and } \\
\text { receives coupons nearby stores } \\
\text { based on Beacon technology. } \\
\text { Since Beacon has small error } \\
\text { range and small amount of } \\
\text { electricity consumption, more } \\
\text { accurate information can be } \\
\text { provided. The paper only } \\
\text { delivers the concept through } \\
\text { theory and good Beacons arent } \\
\text { easily available for practical } \\
\text { implementations. }\end{array}$ \\
\hline
\end{tabular}

Table V: SMART SHELVES AND INDOOR NAVIGATION

\begin{tabular}{|c|c|}
\hline Paper Title & Analysis \\
\hline $\begin{array}{l}\text { Development of } \text { smart } \\
\text { shelf library } \\
\text { usystem } \\
\text { using RFID, MF } \\
\text { Ghazani, NG Chuen, JS } \\
\text { Mandeep, } \\
2012 \text { [18] }\end{array}$ & $\begin{array}{l}\text { A short supply, or an increased } \\
\text { demand, notified via the } \\
\text { dashboard will help in efficient } \\
\text { stock replenishment. Any } \\
\text { change in the stock on-the- } \\
\text { shelf will be signalled to the } \\
\text { system, notifying a conversion } \\
\text { to potential sale. Smart Shelves } \\
\text { are integrated by installing an } \\
\text { ultra-low profile reader in each } \\
\text { of the shelf. }\end{array}$ \\
\hline $\begin{array}{l}\text { SLIMs: Smart } \\
\text { Lightweight Indoor } \\
\text { Maps, Sathittham } \\
\text { Sangthong, Boonchana } \\
\text { Purahong, AttasitLaskul, } \\
2013 \text { [19] }\end{array}$ & $\begin{array}{l}\text { The system uses short length } \\
\text { communication technologies } \\
\text { i.e. NFC combined with QR } \\
\text { Codes, which are very } \\
\text { economical and easily } \\
\text { available. With the positioning } \\
\text { system one can save cost in } \\
\text { term of system infrastructures, } \\
\text { system installation and system } \\
\text { maintenance compared to other } \\
\text { solutions. The application is } \\
\text { only dedicated to in-store } \\
\text { navigation and its integration } \\
\text { in the main application can } \\
\text { increase the size of the } \\
\text { complete application which } \\
\text { might be a problem for users. }\end{array}$ \\
\hline $\begin{array}{l}\text { Development of an } \\
\text { Indoor Navigation } \\
\text { System Using NFC } \\
\text { Technology, Busra } \\
\text { OZDENIZCI, Kerem } \\
\text { OK, } \\
\text { Vedat COSKUN, } \\
\text { Mehmet } \\
\text { N. AYDIN, } 2011 \text { [20] }\end{array}$ & $\begin{array}{l}\text { A spatial information map is } \\
\text { created using the CAD } \\
\text { systems. The user scans the } \\
\text { tags using his phone and the } \\
\text { current location is displayed on } \\
\text { the map.He can then enter his } \\
\text { destination point and the } \\
\text { interface will show the } \\
\text { directions. Dijkstra's shortest } \\
\text { path algorithm is used to } \\
\text { calculate the optimal path. The } \\
\text { algorithm uses Dijkstra's } \\
\text { algorithm to find the shortest } \\
\text { path. The algorithm cannot } \\
\text { detect bottlenecks and crowded } \\
\text { places inside the store and } \\
\text { update the path accordingly. }\end{array}$ \\
\hline
\end{tabular}

\begin{tabular}{|c|c|}
\hline $\begin{array}{l}\text { An Anchor-free } \\
\text { Localization Algorithm } \\
\text { for Shopping Carts on } \\
\text { Supermarket Internet } \\
\text { of Things, Zhongmin } \\
\text { Pei, Yibin Li, Shuo Xu, } \\
2012 \\
{[21]}\end{array}$ & $\begin{array}{l}\text { An anchor-free fast } \\
\text { localization algorithm for large } \\
\text { scale IoT devices along with } \\
\text { an integrated architecture of } \\
\text { SIoT is proposed based on the } \\
\text { analysis of smart supermarket } \\
\text { function. Many anchor nodes } \\
\text { required to find the location of } \\
\text { cart [4 for every grid]. Hence it } \\
\text { is very expensive. }\end{array}$ \\
\hline $\begin{array}{l}\text { Implementation of } \\
\text { Smart Shopping } \\
\text { System based on NFC } \\
\text { Technology, } \\
\text { OuWenxing, } \\
\text { Wang Lei, Jiang } \\
\text { Zhipeng, Yu Changhong, } \\
2015 \text { [22] }\end{array}$ & $\begin{array}{l}\text { It emphasizes on the various } \\
\text { supermarket softwares and its } \\
\text { subsystems. The android app } \\
\text { uses NFC to feature online } \\
\text { payments, refunds and } \\
\text { navigation. There is no real- } \\
\text { time data processing or context } \\
\text { relevant offer sent to the user. } \\
\text { There is still a level of manual } \\
\text { interaction in the initial stages. }\end{array}$ \\
\hline
\end{tabular}

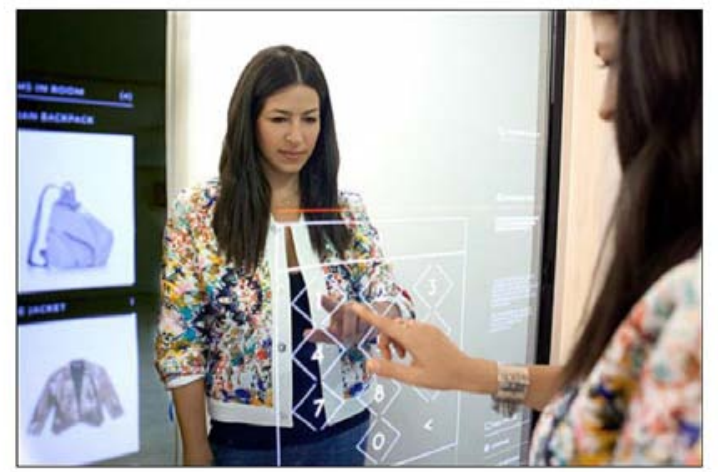

Figure 3. Magic mirror inside the trial room 


\section{PROPOSED ARCHITECTURE}

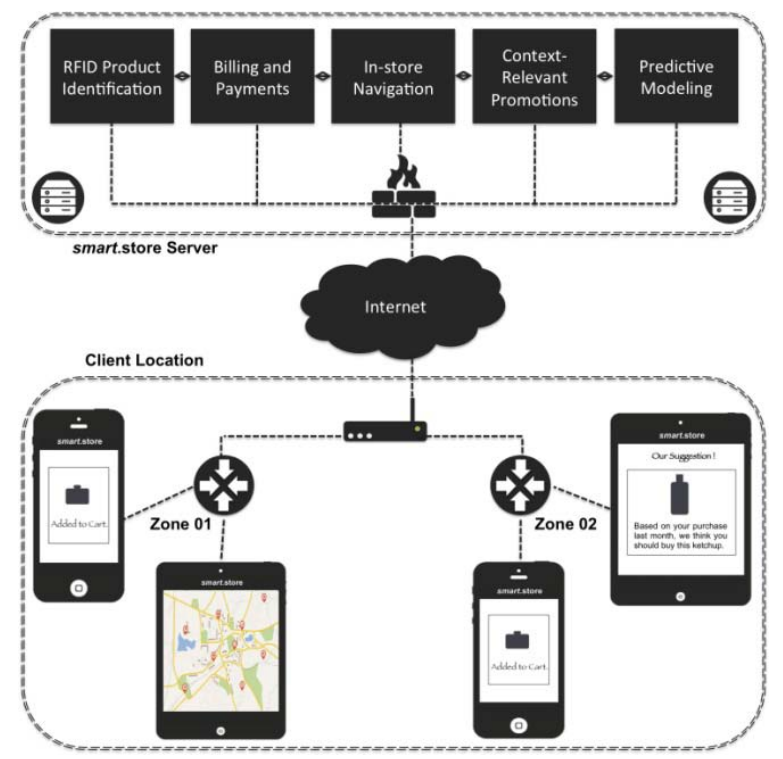

Figure 4. System diagram

The Proposed architecture aims at overcoming all the shortcomings in the existing approaches. The front-end of the proposed system will be deployed as a web application rather than a native application. The issues with native apps include heavy platform dependent maintenance and UI inconsistency.Supplementing all this are the feature-rich web application frameworks like Ionic and Xamarin which allow the developer to seamlessly deploy their application with cross-platform functionality while using Materialize or Bootstrap for the Front-end.

The proposed Web Application will consist of a Live Dashboard, for the real-time inventory control and in-store management of the overall consumer experience. Along with this, the application will also possess the functionality of a one-step purchase as in case of the e-commerce websites today. The products in the store will be available with their information maps to enhance the customer experience and increase the user engagement. The passive Tags (EPC Global Data Standard) will be utilized in the system. Industrial Readers and frequency-based antennas developed By MNCs like Motorola - Zebra will serve as the backbone. The Reader, installed on the cart will be an ultra-low profile reader in order to maintain the proximity of reading only the items that are added to the cart and not those who are over-the-shelf. Another fixed Reader will be used for smart shelves. The operating range is chosen after deciding the architecture of the store for optimization, while eliminating collisions.

Concurrently, the backend of the proposed system will be based on the noSQL Databases. The dynamic nature of the data and high scalability and performance gives MongoDB an edge over the RDBMS. MongoDB is a schema-less Document-oriented Database which allows very high scalability and performance using MapReduce and other aggregation techniques. The RFID Tagged Products will be maintained via this database, along with profiling the Consumer Behaviour and Purchase Pattern, further useful for the Predictive Modelling. Along with this, the proposed system will be capable of the Proximity Marketing in the future. This involves generating and pushing custom contextrelevant promotions to the customer, based on his consumer behaviour in the retail store. The whole system will be deployed in the Cloud Environment to avoid Data Center Management at the developer / integrator level, and optimally utilize the resources for the application deployment. The miFare NFC Tags will be placed at certain reference points or the checkpoints in the store. These will be decided on the basis of the Current Infrastructure Of the Store. The end-user will have a custom Store information map, via the Google Maps Engine and CAD systems. This in-store navigation functionality will further supplement the proximity marketing feature of the proposed system. As soon as a consumer device is localized on the information map, then, based on his user profile, a context-relevant promotion can be pushed onto his device for a potential sale conversion. Another benefit here, accorded by the Web Application in the proposed system, is the extent of customization. The proposed system is adaptable to any custom, yet realistic and feasible needs of the customer and hence, maintains an edge over the native standalone deployments.

\section{CONCLUSION}

The solution discussed in this paper takes care of all the steps of shopping and guides not only the customer but also the enterprise in understanding the customer behaviour and in inventory management. The whole process reduces the reliance of these businesses on manpower and provides and smooth automated flow to customer. RFID technology is reliable and cheap to practically implement. In addition to that, an application to provide information to the customers adds a whole new dimension to the customer experience that is thus far unexplored.

\section{ACKNOWLEDGEMENT}

This literature study has been supported by The Mukesh Patel School Of Technology Management and Engineering, NMIMS, Mumbai. We thank Mr. Sanjay Dighe, Director, Worth Technology Pvt. Ltd. for his assistance. His subject expertise and grip on the market has assisted us in shaping this proposed approach and understand the trending, yet agile customer needs in the scope of this solution.

\section{REFERENCES}

[1] YerlanBerdaliyev, Alex Pappachen James RFID-Cloud Smart Cart Sys-tem, in 2016 Intl. Conference on Advances in Computing, Communica-

tions and Informatics (ICACCI), Sept. 21-24， 2016， Jaipur, India.

[2] Zeeshan Ali and ReenaSonkusare RFID based Smart Shopping: An Overview. in International Conference on Advances in Communication and Computing Technologies, 2014. 
[3] Dr.ShefaliGupta,A. Kaur,A. Garg,A. Verma, A. Bansal,A. Singh Arduino based Smart Cart, in International Journal of Advanced Research in

Computer Engineering and Technology (IJARCET),December, 2013.

[4] FangweiZheng, Jeffrey Huang, Mark Meagher The Introduction andDesign of a New Form of Supermarket: Smart Market,2009.

[5] M.Mathan Kumar, N.Sugandhi A Low Cost Smart Shopping FacilitatorFor Visually Impaired, IEEE, 2013.

[6] Rong Chen, Li Peng, Yi Qin Supermarket Shopping Guide System based on Internet Of Things, School of IoT Engineering, Jiangnan University, 2016.

[7] Hsin-Han Chiang, Wan-Ting You, Shu-Hsuan Lin, Wei-Chih Shih, Yu-Te Liao, Jin-Shyan Lee, and Yen-Lin Chen, Development of Smart Shop-ping Carts with Customer-Oriented Service, International Conference onSystem Science and Engineering (ICSSE) 2016 , National Chi Nan University, Taiwan, July 7-9, 2016.

[8] Abhirup Khanna and Ravi Tomar IOT based Interactive Shopping Ecosys-tem in 2016 2nd International Conference on Next Generation Computing Technologies (NGCT-2016) Dehradun, India 14-16 October 2016

[9] Sudhir Rao Rupanagudi, FathimaJabeen, Vaishnav Ram Savarni K R, SindhuAdinarayana, Vinay K Bharadwaj, Karishma R, VarshaG.Bhat A Novel Video Processing based Cost Effective Smart Trolley System forSupermarkets using FPGA in International Conference on Communica-tion, Information and Computing Technology (ICCICT) , Jan. 16-17, Mumbai, India

[10] You-Chiun Wang, Chang-Chen Yang 3S-cart: A Lightweight, InteractiveSensor-Based Cart for Smart Shopping in Supermarkets in IEEE SEN-SORS JOURNAL, VOL. 16, NO. 17, SEPTEMBER 1, 2016.

[11] Ravi. V, Aparna. R, Security in RFID based Smart Retail System,in International Conference on Computing for Sustainable Global Development (INDIACom), IEEE 2016, pp. 587-592.

[12] Weiping Zhu, Yi Hong, VaskarRaychoudhury, Run Zhao and Dong Wang A Distributed RFID Reader Activation Approach in 23rd Inter-national Symposium on Quality of Service (IWQoS), IEEE, 2015.

[13] Cheng-kung, Yu-kuang Hsieh, Yung-hau Wang, Ching-ter Chang Aware and Smart Member Card: RFID and License Plate Recognition SystemsIntegrated Applications at Parking Guidance in Shopping Mall 8th In-ternational Conference on
Advanced Computational Intelligence, Chiang Mai, Thailand; February 14-16, 2016

[14] Chuang Wang, Pingyu Jiang Cognitive Computing based ManufacturingData Processing for Internet of Things in JobShop Floor in IEEE International Conference on Mechatronics and Automation, August 02-05, Beijing, China, 2015.

[15] AnkushYewatka, FaizInamdar, Raj Singh, Ayushya, AmolBandal Smart Cart with Automatic Billing, Product Information, Product Rec-ommendation Using RFID and Zigbee with Anti-Theft in IEEE In-ternational Conference On Recent Trends In Electronics Information Communication Technology, May 20-21, 2016, India

[16] Sanga Son and Yongtae Shin Design of Smart Shopping ApplicationUsing Barcode Scanning and Location Based Coupon Service in 8th International Conference on Grid and Distributed Computing, 2015.

[17] Ezhilazhagan.C, Adithya.R, Burhanuddin.Y. L, Charles.F Automated Product Detection and Smart Billing for Shopping using Li-Fi in IEEE International Conference On Recent Trends In Electronics Information Communication Technology, May 20-21, 2016, India

[18] Mandeep, J. S., Chuen, N. G., and Ghazali, Development of a smart shelf library system using RFID, in Advances in Natural and Applied Sciences, 2012, pg 235-240

[19] SathitthamSangthong, P. Boonchana, L. Attasit, SLIMs: Smart Lightweight Indoor Maps, in 2nd International Symposium on Com- puter, Communication, Control and Automation 2013.

[20] BusraOzdenizci, O. Kerem,C. Vedat,A. Mehmet N. AYDIN, Develop- ment of an Indoor Navigation System Using NFC Technology, in Infor- mation and Computing (ICIC), Fourth International Conference,April, 2011

[21] Zhongmin Pei, Yibin Li, ShuoXuAn An Anchor-free Localization Algorithm for Shopping Carts on Supermarket Internet of Things in $2^{\text {nd }}$ International Conference on Computer Science and Network Technology, 2012.

[22] OuWenxing, Wang Lei, Jiang Zhipeng, Yu Changhong Implementation of Smart Shopping System based on NFC Technology in Seventh International Conference on Measuring Technology and Mechatronics Automation, 2016.

[23] Rebecca Minkoff Brings Self-Service to Its SoHo Store With RFID, http://www.rfidjournal.com/articles/view?15427, in Information and Com- puting (ICIC), Fourth International Conference, 21 December, 2016. 